\title{
STUDI KUALITAS AIR BERDASARKAN PARAMETER FISIKA DAN KIMIA PADA AIR GUA DESA LABURUNCI KABUPATEN BUTON
}

\author{
Ni'ma Meilani, Sadam Sudin Sahi \\ Fakultas Kesehatan Masyarakat Universitas Dayanu Ikhsanuddin Baubau
}

\begin{abstract}
Water is a basic requirement for human life. Clean water sources used by village communities apart Laburunci comes from taps Kabupaten Buton also sourced from springs Caves Village Laburunci. Recorded in March 2015 as many as 235 households use water cave, but until now there has been no student or institutions that conduct scientific research to determine the water quality of the cave. This study aims to determine the water quality of Cave Village Laburunci Buton based on physical and chemical parameters. This type of research is observational dekskriptif, a total sample of 149 with a simple random sampling technique. The research instruments were questionnaires, observation sheets, and laboratory instruments. Research results from the analysis based on the Minister of Health No. 416/Men.Kes/Per/IX/1990 concerning requirements and Water Quality Monitoring. The results showed that for the physical parameters, the artist smell is known of the 149 respondents stating no smell. This is in contrast to the parameters of taste and color where there are two respondents stated that taste and a third of respondents stated that colorless. For chemical parameters such as $\mathrm{pH}$ and $\mathrm{DO}$ is known that the $\mathrm{pH}$ value of the water cave at 7.87 while $\mathrm{DO}$ is at 7.3 $\mathrm{mg} / \mathrm{l}$. Thus we can conclude that both physical parameters and chemical parameters, based Permenkes No. 416/Men.Kes/Per/IX/1990 concerning requirements and Monitoring Water Quality, Air Caves Village Laburunci eligible for use in meeting the needs of the household. Laburunci need for villagers, village government and related agencies to work together to protect water quality Laburunci Gua village located in the village of Laburunci Buton.
\end{abstract}

\section{Keywords: Water quality, physical parameters, chemical parameters}

\section{PENDAHULUAN}

Kualitas lingkungan yang sehat dan tidak tercemar salah satunya dapat dilihat dari kualitas air yang digunakan manusia sebagai pokok penunjang aktivitas dalam kehidupan manusia. Air merupakan media lingkungan yang tidak dapat dipisahkan dari manusia dalam kehidupannya. Namun seiring perkembangan teknologi pencemaran terhadap lingkungan air terjadi secara besar-besaran yang menyebabkan kualitas air semakin menurun (Soemirat dalam Hamzah, 2014).

Sumber-sumber air dicari untuk diolah dalam pengembangan penyediaan air bagi masyarakat. Salah satu sumber air tersebut adalah air permukaan. Keberadaan air tidak lepas dari siklus hidrologi. Dengan adanya siklus tersebut maka air akan bersentuhan dengan senyawa sehingga air terkontaminasi dengan bahan lain. Jadi tidak ada air yang benar-benar murni. Pertumbuhan penduduk yang begitu pesat telah meningkatkan aktivitas manusia untuk memenuhi kebutuhan disegala sektor. Peningkatan ini mengakibatkan peningkatan intensitas pencemaran terhadap sumber daya air yang tersedia. Ditambah lagi perubahan teknologi baru yang dapat mencemari lingkungan seperti detergen, pupuk, pestisida dan lain-lain. Semakin menambah rusak sumber daya air permukaan yang tersedia (Sumantri dalam Hamzah, 2014).

Desa Laburunci merupakan salah satu Desa yang berada di Kecamatan Pasarwajo Kabupaten Buton. Desa Laburunci terdiri atas 4 Dusun yaitu Dusun Awasurabi, Dusun Awarapia, Dusun Awaungge dan Dusun Amaandia. Data dari Kantor Desa disebutkan bahwa jumlah penduduk di Desa Laburunci sebanyak 3.163 jiwa dan jumlah kepala keluarga (KK) sebanyak 652 kepala keluarga (Profil Desa Laburunci, 2014).

Masyarakat di Desa Laburunci menggunakan fasilitas air bersih PDAM Kabupaten Buton dalam mencukupi kebutuhan sehari-hari dalam hal sumber daya air, namun ada juga sebagian masyarakat yang menggunakan air Gua sebagai sumber air bersih. Terhitung sejak tahun 2011 - Maret 2015, jumlah pengguna air Gua Desa Laburunci sebanyak 36\% (Profil Desa Laburunci. 2015). Banyaknya jumlah pengguna air Gua tersebut didukung oleh masuknya proyek perpipaan 
lewat program PNPM-MP Tahun Anggaran 2011. Faktor lain karena murahnya tarif perbulan pengguna air Gua dibanding mereka yang menggunakan air PDAM Kabupaten Buton.

Letak permasalahannya adalah jumlah pemakai air Gua dari hari ke hari semakin meningkat namun mereka tidak mengetahui apakah air tersebut layak atau tidak jika digunakan sebagai sumber air bersih. Bahkan berdasarkan pengakuan dari aparat Desa setempat, sebelum dan setelah penyaluran air Gua secara besar-besaran melalui proyek perpipaan, belum ada lembaga penelitian yang mengambil sampel air untuk di teliti terlebih dahulu di laboratorium dan menunjukan bahwa air Gua tersebut layak atau tidak jika di gunakan untuk memenuhi kebutuhan rumah tangga. Mereka berasumsi bahwa sudah sejak lama menggunakan air Gua tersebut namun belum ada masalah kesehatan yang mereka alami.

Tosepu (2010) mengatakan bahwa kualitas air tanah dipengaruhi oleh beberapa faktor antara lain faktor alamiah dan akfifitas manusia. Pengaruh kedua hal tersebut dapat menyebabkan terjadinya penurunan kualitas, sehingga air tanah menjadi tidak layak untuk dikonsumsi sebagai air bersih.

\section{METODE}

\section{Jenis Penelitian}

Jenis penelitian yang digunakan dalam penelitian ini adalah observasional deskriptif. Dalam penelitian ini penulis bermaksud melihat, mengukur dan menggambarkan kualitas air Gua Desa
Laburunci Kecamatan Pasarwajo Kabupaten Buton.

\section{Populasi dan Sampel}

Populasi dalam penelitian ini adalah seluruh masyarakat Desa Laburunci yang menggunakan air Gua Desa Laburunci sebagai sumber air bersih rumah tangga yang berjumlah 235 Kepala Keluarga.

Sampel dalam penelitian ini terbagi atas dua bagian, yaitu sampel untuk penelitian fisika dan sampel untuk penelitian kimia.

1. Sampel Fisika

Untuk mengetahui besarnya sampel dihitung dengan menggunakan rumus slovin sehingga diperoleh jumlah sampel sebanyak 149 KK. Metode penarikan sampel dengan menggunakan metode simple random sampling". Acak sederhana yang digunakan yaitu seperti pengundian lot arisan.

2. Sampel Kimia

Berbeda dengan penentuan sampel pada parameter fisika yang harus menggunakan metode tertentu, pada parameter kimia langsung melakukan penelitian pada sumber air gua Desa Laburunci yang berjumlah satu sumber mata air.

\section{HASIL PENELITIAN}

Hasil Pengukuran Air Gua Desa Laburunci

\section{Berdasarkan Parameter Fisika}

Distribusi responden berdasarkan parameter fisika yaitu bau air Gua Desa Laburunci Kabupaten Buton seluruhnya tidak berbau dengan frekuensi 149 responden (100\%), yang dapat dilihat pada tabel berikut:

Tabel 1. Distribusi Jawaban Responden berdasarkan Bau, Rasa dan Warna Air Gua Desa Laburunci Kabupaten Buton Tahun 2015

\begin{tabular}{lcc}
\hline \multicolumn{1}{c}{ Parameter yang Diteliti } & Frekuensi & Persentase \\
\hline Parameter Bau Air & & \\
$\quad$ Berbau & 0 & 0 \\
$\quad$ Tidak Berbau & 149 & 100 \\
Parameter Rasa Air & & \\
$\quad$ Berasa & 2 & 1,3 \\
$\quad$ Tidak Berasa & 147 & 98,7 \\
Parameter Warna Air & & \\
$\quad$ Berwarna & 3 & 2 \\
$\quad$ Tidak Berwarna & 146 & 98 \\
\hline
\end{tabular}

Hasil Pengukuran Kualitas Air Gua Desa Laburunci berdasarkan Parameter Kimia

\section{Power Hidrogen (pH)}

Hasil pengukuran nilai $\mathrm{pH}$ air Gua Desa Laburunci dapat dilihat pada gambar di bawah : 


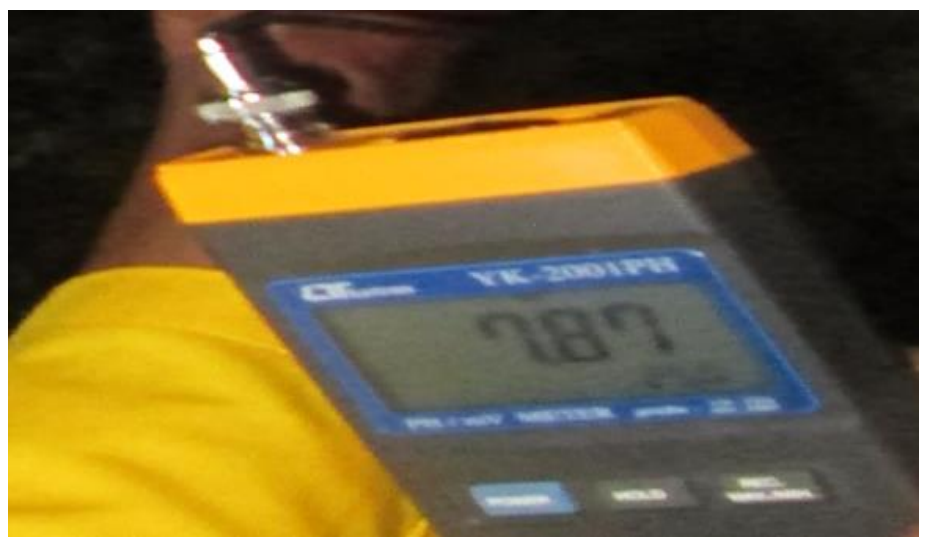

Gambar 1. Nilai pH Air Gua Desa Laburunci Tahun 2015

Gambar 1 menunjukan bahwa pH air Gua Desa Laburunci berada pada frekuensi 7,87. Sesuai Peraturan Menteri Kesehatan No. 416/Men.Kes/Per/IX/1990 tentang syarat-syarat dan Pengawasan Kualitas Air, nilai $\mathrm{pH}$ yang memenuhi syarat yaitu $6,5-8,5$.

\section{Disolved Oxygen (DO)}

Hasil pengukuran nilai DO air Gua Desa Laburunci dapat dilihat pada gambar di bawah ini:

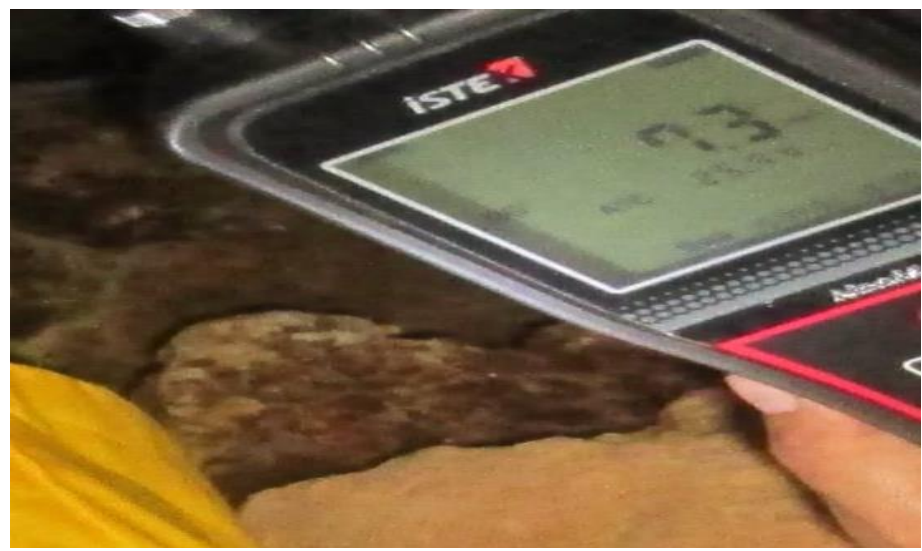

\section{Gambar 2. DO Air Gua Desa Laburunci Tahun 2015}

Gambar 2. menunjukan bahwa DO air Gua Desa Laburunci berada pada frekuensi 7,3. Sesuai Peraturan Menteri Kesehatan No. 416/Men.Kes/Per/IX/1990 tentang Syaratsyarat dan Pengawasan Kualitas Air, nilai DO yang memenuhi syarat yaitu minimal 6,0 mg/L.

\section{PEMBAHASAN}

Hasil penelitian melalui sebaran kuisioner kepada 149 responden pengguna air Gua Desa Laburunci untuk mengukur parameter fisika berupa bau air, diketahui tidak ada diantara responden yang menyatakan air Gua yang digunakan berbau (Tabel. 1) dengan persentasi $100 \%$. Hal ini juga berkesesuaian dengan hasil observasi peneliti ke sumber mata air gua desa laburunci yang menunjukan air gua tersebut tidak berbau.
Tidak adanya bau pada air Gua Desa Laburunci terjadi karena sumber mata air tersebut memanjang ke samping dengan jarak 40 meter dari permukaan tanah, dengan begitu maka sumber pencemar yang berasal dari luar Gua tidak langsung dapat bersentuhan dengan sumber mata air.

Selain bau, rasa air merupakan parameter penting dalam mengukur kualitas air. Parameter-parameter tersebut merupakan sifat fisik yang secara langsung berpengaruh terhadap pengguna air. Hasil penelitian melalui sebaran kuisioner kepada 149 responden pengguna air Gua Desa Laburunci, untuk parameter rasa diketahui terdapat 2 responden yang menyatakan air gua yang mereka gunakan berasa dengan presentasi 1,3\%, sementara 147 lainnya menyatakan air gua yang mereka gunakan tidak berasa dengan presentasi 98,7\%. 
Secara fisika, air dapat dirasakan oleh lidah. Adanya rasa pada sejumlah responden pengguna air dimungkinkan terjadi karena berdasarkan jawaban yang dari responden berdasarkan kuesioner yang ada dan berdasarkan pengakuan dari pengguna air (responden) tersebut mengatakan jarang membersihkan tempat penampungan air yang mereka miliki sehingga bisa saja terdapat zat organik atau bakteri unsur lain yang masuk kedalam penampung air. Karena pengukuran rasa tergantung pada reaksi individu, maka hasil yang dilaporkan tentu bergantung pada subjektivitas masing-masing.

Sependapat dengan 147 responden tentang tidak berasanya air gua tersebut, hasil observasi langsung peneliti pada sumber mata air Gua Desa Laburunci, untuk parameter fisika berupa rasa, diketahui air Gua Desa Laburunci tidak berasa.

Warna air merupakan parameter fisika yang tidak kalah penting dari parameterparameter lainnya. Dari 149 responden yang diteliti, terdapat 3 responden yang menyatakan air Gua yang mereka gunakan berwarna dengan presentasi 2\% dan 146 lainnya menyatakan air gua yang mereka gunakan tidak berwarna. Adanya warna pada sejumlah responden disebabkan karena pengguna air Gua tersebut jarang membersihkan penampung air yang di gunakan. Selain itu adanya warna air dimungkinkan terjadi, sebab selain menggunakan air Gua mereka juga berlangganan air PDAM Kabupaten Buton dalam penampung yang sama. Sementara air PDAM yang tertampung kadang berwarna merah ke kuningan.

Sependapat dengan 146 responden tentang tidak berwarnanya air gua tersebut, hasil observasi langsung peneliti pada sumber mata air Gua Desa Laburunci, untuk parameter fisika berupa warna air, diketahui air Gua Desa Laburunci tidak berwarna.

Hasil pemeriksaan kualitas air Gua Desa Laburunci secara kimia memperlihatkan bahwa nilai $\mathrm{pH}$ air Gua Desa Laburunci adalah 7,87. Nilai $\mathrm{pH}$ tersebut dimungkinkan terjadi, karena adanya kontak yang intens antara air dan batu kapur yang terdapat di dalam gua. Keberadaan batu kapur sangat mempengaruhi tingkat basa air, sebab Batuan kapur bersifat basa. Selain itu, pH 7,87 pada air gua Desa Laburunci dimungkinkan terjadi, karena Gua itu terbuka untuk umum dan hanya terpaut beberapa meter antara bibir gua dan jalan beraspal. Sehingga bisa jadi ada diantara masyarakat yang memanfaatkannya untuk mencuci atau hanya sekedar singgah membersihkan sesuatu dengan sabun deterjen.Apalagi sumber mata air tersebut tidak jarang dijadikan tempat singgah sebentar para petani sebelum atau sesudah berkebun.

Nilai $\mathrm{pH}$ berkisar antara $0-14, \mathrm{pH}$ kurang dari 7 menunjukkan lingkungan yang asam sedangkan nilai diatas 7 menunjukkan lingkungan yang basa, untuk $\mathrm{pH}$ sama dengan 7 disebut sebagai netral (Sumantri, 2010). Untuk dapat mengetahui kualitas air berdasar parameter kimia, selain melalui $\mathrm{pH}$ juga dapat dilakukan dengan mengukur nilai DO air. Hasil pemeriksaan kualitas air Gua Desa Laburunci secara kimia memperlihatkan bahwa nilai DO air Gua Desa Laburunci adalah 7,3 mg/L.

Tanpa adanya oksigen terlarut, banyak mikroorganisme dalam air tidak dapat hidup karena oksigen terlarut digunakan untuk proses degradasi senyawa organik dalam air. Semakin besar kandungan DO pada air, mengindikasikan air tersebut memiliki kualitas yang bagus. Sebaliknya jika nilai DO rendah, dapat diketahui bahwa air tersebut telah tercemar (Mulia, 2005).

\section{KESIMPULAN}

Secara fisika air Gua Desa Laburunci Kabupaten Buton telah memenuhi syarat kesehatan. Secara kimia air Gua Desa Laburunci telah memenuhi syarat kesehatan.

\section{DAFTAR PUSTAKA}

Hamzah. (2015). Studi Eksperimen tentang Efektivitas Tawas dan Poly Aluminium Chloride Terhadap Perubahan Kualitas Air (PH dan TSS) di Kecamatan Loa Janan Ilir Samarinda Kalimantan Timur, http://hamzahsiomnivora.blogspot.co.id.

Diakses tanggal 27 Mei 2015.

Mulia, Ricki M. (2005). Kesehatan Lingkungan. Edisi Pertama, Yogyakarta : Graha Ilmu.

Profil Desa Laburunci Tahun 2014.

Profil Desa Laburunci Tahun 2015.

Sumantri, Arif. (2010). Kesehatan Lingkungan Dan Perspektif Islam. Jakarta: Penerbit Kencana.

Tosepu, Ramadhan. (2010). Kesehatan Lingkungan. Surabaya, Penerbit: Bintang Surabaya. 